\title{
The Eurasian Dry Grassland Group (EDGG) in 2016-2017
}

\author{
Stephen Venn ${ }^{1,2, *}$, Didem Ambarlı ${ }^{3}$, Idoia Biurrun ${ }^{4}$, Jürgen Dengler ${ }^{5,6,7}$, \\ Anna Kuzemko ${ }^{8}$, Péter Török ${ }^{9} \&$ Michael Vrahnakis ${ }^{10}$
}

Keywords: conservation, Eurasian Dry Grassland Group (EDGG), fauna, grassland, GrassPlot, Palaearctic, vegetation, vegetationplot database.

Ključne besede: ohranjanje, Evrazijska skupina za suha travišča (EDGG), favna, travišče, GrassPlot, Palearktik, vegetacija, vegetacijska podatkovna baza.
Received: 7. 2. 2018

Accepted: 7. 2. 2018

\section{Co-ordinating Editor: \\ Orsolya Valkó}

\begin{abstract}
This report summarizes the activities and achievements of the Eurasian Dry Grassland Group (EDGG) from mid-2016 through to the end of 2017. During this period, the $13^{\text {th }}$ Eurasian Grassland Conference took place in Sighişoara, Romania, and the $14^{\text {th }}$ conference was held in Riga, Latvia. The $10^{\text {th }}$ EDGG Field Workshop on Biodiversity patterns across a precipitation gradient in the Central Apennine mountains was conducted in the Central Apennines, Italy, this time in addition to multi-scale sampling of vascular plants, bryophytes and lichens, also including one animal group (leaf hoppers). Apart from the quarterly issues of its own electronic journal (Bulletin of the Eurasian Dry Grassland Group), EDGG also finalised five grassland-related Special Features/Issues during the past 1.5 years in the following international journals: Applied Vegetation Science, Biodiversity and Conservation, Phytocoenologia, Tuexenia and Hacquetia. Beyond that, EDGG facilitated various national and supra-national vegetationplot databases of grasslands and established its own specialised database for standardised multi-scale plot data of Palaearctic grasslands (GrassPlot).

\section{Izvleček}

$\mathrm{V}$ poročilu predstavljamo aktivnosti in dosežke Evrazijske skupine za suha travišča (EDGG) od sredine leta 2016 do konca leta 2017. V tem obdobju sta potekali 13. evrazijska konferenca o traviščih v mestu Sighişoara v Romuniji in 14. konferenca v Rigi v Latviji. Deseta EDGG terenska delavnica o Vzorcih biodiverzitete vzdolž padavinskega gradienta v Centralnih Apeninih v Italiji je potekala skupaj z vzorčenjem cevnic, mahov, lišajev in škržatov na različno velikih ploskvah. Poleg rednih lastnih četrtletnih elektronskih izdaj (Bulletin of the Eurasian Dry Grassland Group) je skupina v preteklem letu in pol izdala tudi pet posebnih številk oziroma tematskih delov v mednarodnih revijah, posvečenih traviščem: Applied Vegetation Science, Biodiversity and Conservation, Phytocoenologia, Tuexenia in Hacquetia. Skupina EDGG je vzpodbudila tudi nastanek različnih nacionalnih in mednarodnih vegetacijskih podatkovnih zbirk in vzpostavila lastno specializirano podatkovno zbirko za standizirane večrazsežnostne vegetacijske ploskve palearktičnih travišč (GrassPlot).
\end{abstract}

1 Ecosystems and Environment Research Programme, Faculty of Biological and Environmental Sciences, University of Helsinki, P.O. Box 65 (Viikinkaari 2a), 00014, Finland. E-mail: stephen.venn@helsinki.fi

2 Department of Architecture, Aalto University, P.O. Box 16500 (Miestentie 3), 00076 Aalto, Finland. E-mail: stephen.venn@helsinki.fi

3 Faculty of Agriculture and Natural Sciences, Düzce University, Konuralp Campus, 81620 Düzce, Turkey. E-mail: didem.ambarli@gmail.com

4 Department of Plant Biology and Ecology, University of the Basque Country UPV/EHU, P.O.Box 644, 48080 Bilbao, Spain. E-mail: idoia.biurrun@ehu.es

5 Vegetation Ecology Group, Institute of Natural Resource Sciences (IUNR), Zurich University of Applied Sciences (ZHAW), Grüentalstr. 14, 8820 Grüental, Switzerland

6 Plant Ecology, Bayreuth Center for Ecology and Environmental Research (BayCEER), University of Bayreuth, Universitätsstr. 30,95447 Bayreuth, Germany. E-mail: juergen.dengler@uni-bayreuth.de

7 German Centre for Integrated Biodiversity Research (iDiv) Halle-Jena-Leipzig, DeutscherPlatz 5e, 04103 Leipzig, Germany

8 Geobotany and Ecology Department, M.G. Kholodny Institute of Botany, National Academy of Sciences of Ukraine, 2, Tereshchenkivska str. Kyiv, 01601 , Ukraine. E-mail: anyameadow.ak@gmail.com

9 MTA-DE Lendület Functional and Restoration Ecology Research Group, Egyetem sqr. 1, 4032, Debrecen, Hungary. E-mail: molinia@gmail.com

10 Department of Forestry and Management of Natural Environment, Technological University of Thessaly, 43100, Karditsa, Greece. E-mail: mvrahnak@teilar.gr 
This report provides an overview of the activities and achievements of the Eurasian Dry Grassland Group (EDGG; http://www.edgg.org) since the last such report (Venn et al. 2016), that is, from mid-2016 to the end of 2017. The EDGG is a network of researchers and conservation practitioners interested in any type of natural and semi-natural grasslands of the Palaearctic biogeographic realm. It was founded in 2008 and currently has 1265 members from 67 countries (January 2018) (also see Vrahnakis et al. 2013). Whilst the EDGG has the status of a working group of the International Association of Vegetation Science (IAVS; http://www.iavs.org), it is not restricted to vegetation, but equally deals with flora, fauna, soils, ecosystem services etc. of grasslands. The main activities of the EDGG are (i) the facilitation of international communication between researchers, conservationists, site managers, policy and decision-makers; (ii) coordination of scientific and policy-related actions in grassland research, conservation and restoration in the whole Palaearctic; (iii) promotion of the development of databases for grassland classification, best-practices in conservation and restoration; (iv) organisation of annual events, such as the Eurasian Grassland Conferences (EGCs) and Field Workshops; and (v) the dissemination of research results, news and information in the EDGG Bulletin, as well as research papers in Special Features of scientific journals, such as Hacquetia, Phytocoenologia, Tuexenia, Biodiversity and Conservation and Applied Vegetation Science.

Further information about the EDGG can be found from our website http://www.edgg.org/ and from our Facebook group https://www.facebook.com/groups/ 938367279561202/. Membership of the EDGG is free of charge and open to anyone who is interested in Palaearctic grasslands. If you would like to become a member, then simply send an e-mail to our Membership Administrator, Idoia Biurrun (idoia.biurrun@ehu.es).

The biennial election of our governing body, the Executive Committee (EC), in spring 2017 saw the departure of founder member Monika Janišová, who decided not to stand for re-election. Eight candidates stood in the EC elections, of which seven were duly elected for the term 2017-2019 (Table 1).

\section{Events of the EDGG in 2016-2017}

The $13^{\text {th }}$ EGC took place in Sighişoara, Romania, in September 2016 with the theme of Management and conservation of semi-natural grasslands: from theory to practice (Sutcliffe et al. 2016). It was organized jointly by Fundația ADEPT and Babeș-Bolyai University, Faculty of Bio-
Table 1: The members of the Executive Committee (EC) of the EDGG subsequent to the election in 2017 and their responsibilities.

Tabela 1: Člani izvršnega odbora (IO) EDGG po volitvah leta 2017 in njihove zadolžitve.

\begin{tabular}{|c|c|}
\hline EC Member & Role \\
\hline Didem Ambarlı & $\begin{array}{l}\text { Editor-in-Chief of the Website; Deputy } \\
\text { IAVS Representative and Treasurer; } \\
\text { Deputy Conference Coordinator }\end{array}$ \\
\hline Idoia Biurrun & $\begin{array}{l}\text { Membership Administrator; Deputy } \\
\text { Editor-in-Chief of EDGG Bulletin; } \\
\text { Deputy Field Workshop Coordinator; } \\
\text { Deputy Officer of the Website }\end{array}$ \\
\hline Jürgen Dengler & $\begin{array}{l}\text { Coordinator for Special Features; Field } \\
\text { Workshop Coordinator }\end{array}$ \\
\hline Anna Kuzemko & $\begin{array}{l}\text { Editor-in-Chief of EDGG Bulletin; } \\
\text { Facebook Group Administrator }\end{array}$ \\
\hline Péter Török & $\begin{array}{l}\text { IAVS Representative and Treasurer; } \\
\text { Deputy Coordinator for Special Features }\end{array}$ \\
\hline Stephen Venn & $\begin{array}{l}\text { Secretary-General; Deputy Facebook } \\
\text { Group Administrator }\end{array}$ \\
\hline Michael Vrahnakis & Conference Coordinator \\
\hline
\end{tabular}

logy and Geology and our hosts were Nat Page, Liliana Gherghiceanu, Cristi Gherghiceanu, Laura Sutcliffe and Razvan Popa. Participants joined four oral presentation sessions, a poster session, three workshops on scientific writing, National Grassland Databases and the science-policy interface, keynote talks by Joern Fischer, Cristina Craioveanu and László Rákosy, as well as mid and post-conference excursions to diverse semi-natural grasslands. The conference provided an opportunity to see the best examples of sustainable land management in Romania for biodiversity, livelihood and culture. The subsequent $14^{\text {th }}$ EGC was jointly organized in Latvia and Lithuania in July 2017, on the topic of Semi-natural grasslands across borders (Rūsina et al. 2017; Figure 1). It provided an opportunity to attend a workshop for beginners on using the $\mathrm{R}$ programme, hear about comprehensive studies of semi-natural grasslands in the Baltics and two keynote talks, by Irina Herzon and Aveliina Helm, as well as three excursions to a range of relevant habitats. The event was hosted by the University of Latvia, the Latvian Botanical Society and the Nature Research Centre in Lithuania and our hosts were Solvita Rūsina, Lauma Gustina, Rūta Sniedze-Kretalova, Valerijus Rašomavičius, Domas Uogintas and Inese Silamikele. The $15^{\text {th }}$ Eurasian Grassland Conference, on the topic of Cooperating for grassland conservation, will be held on $4^{\text {th }}-8^{\text {th }}$ June 2018 , in Sulmona, Central Italy, organized by Sabina Burrascano, Giampiero Ciaschetti, Eleonora Giarrizzo, Emanuela Carli, Eva Del Vico and Laura Facioni. 


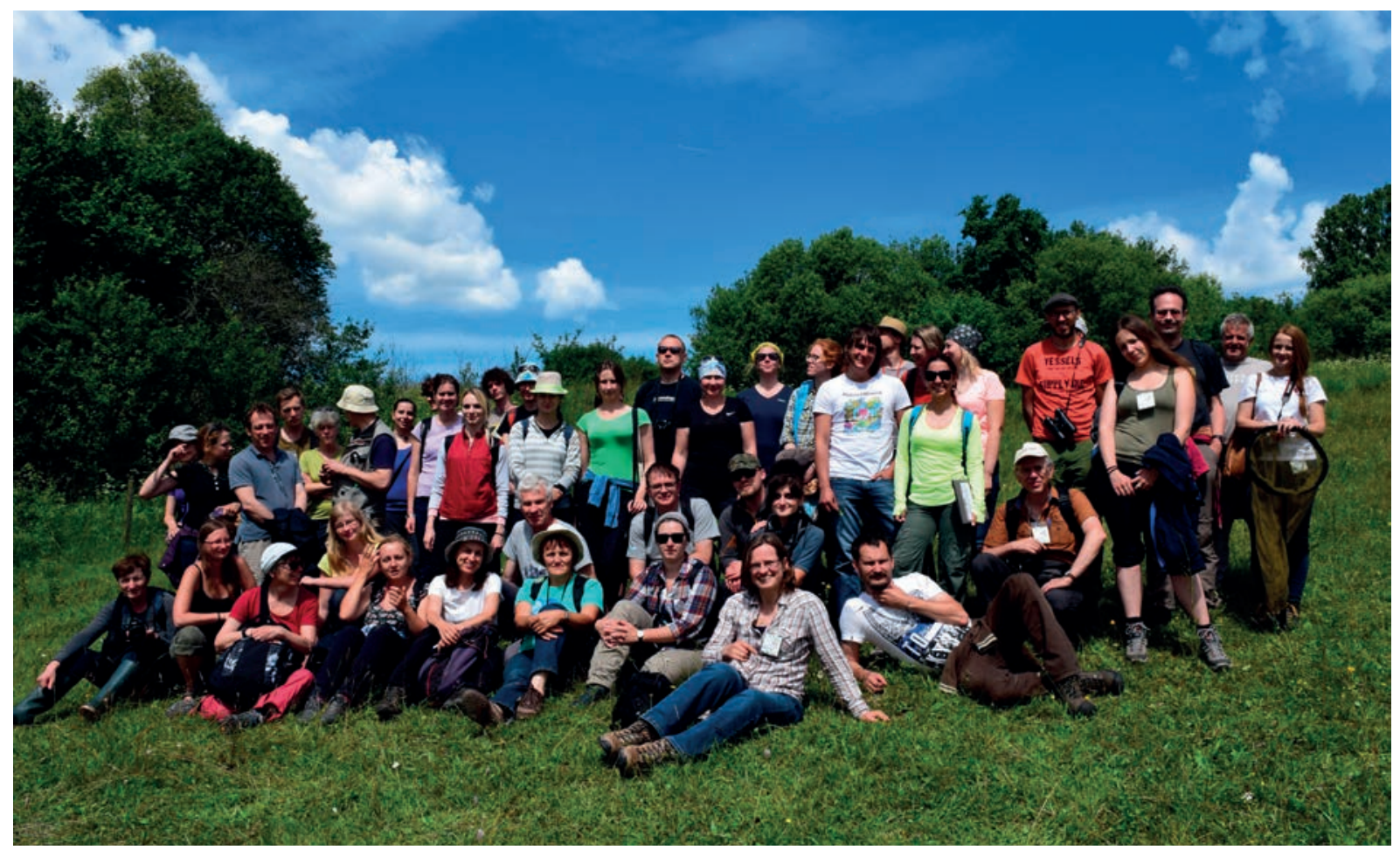

Figure 1: Group photo from mid-conference excursion of the 14th Eurasian Grassland Conference in Latvia, in July 2017 (Photo: R. Sniedze-Kretalova).

Slika 1: Skupinska slika na ekskurziji med 14. evrazijsko konferenco o traviščih v Latviji julija 2017 (Foto: R. Sniedze-Kretalova).

Since 2009 (Dengler et al. 2009), the EDGG Field Workshops (formerly: EDGG Research Expeditions) have comprised the second major regular EDGG event that increasingly attracts grassland specialists of many countries and of any academic level, from BSc. student to professor (see Vrahnakis et al. 2013, Dengler et al. 2016a). The $10^{\text {th }}$ Field Workshop on Biodiversity patterns across a precipitation gradient in the Central Apennines was held in Italy from $3^{\text {rd }}-11^{\text {th }}$ June 2017 (Figure 2). The main organizers were Goffredo Filibeck and Laura Cancellieri (University of Tuscia, Viterbo), supported by Marta G. Sperandii (University of Roma Tre) and Anna Rita Frattaroli. This workshop saw the introduction of some modifications of the standard EDGG protocol (Dengler et al. 2016b), such as the implementation of the assessment of observer-related error, a detailed grazing load assessment and sampling of Auchenorrhyncha (Filibeck et al. 2018). Four oral presentations were given by the participants, and 20 biodiversity plots and an additional 57 normal rel-

Figure 2: Sampling the first biodiversity plot during the 10th EDGG Field Workshop in the Central Apennines, Italy, June 2017 (Photo: D. Frank)

Slika 2: Vzorčenje prve biodiverzitetne ploskve med 10. EDGG terensko delavnico v Centralnih Apeninih v Italiji junija 2017 (Foto: D. Frank) evés were sampled (Dengler et al. 2016b). Quality assessment was performed on ca. $12 \%$ of the plots. The $11^{\text {th }}$ EDGG Field Workshop will be held in the Eastern Alps, Austria from $6^{\text {th }}-13^{\text {th }}$ July 2018, with Martin Magnes, Philipp Kirschner and Helmut Mayrhofer as the local organizers. The idea is to resample sites already covered by the classical monograph of Braun-Blanquet (1961) using a modern methodology (Dengler et al. 2016b).

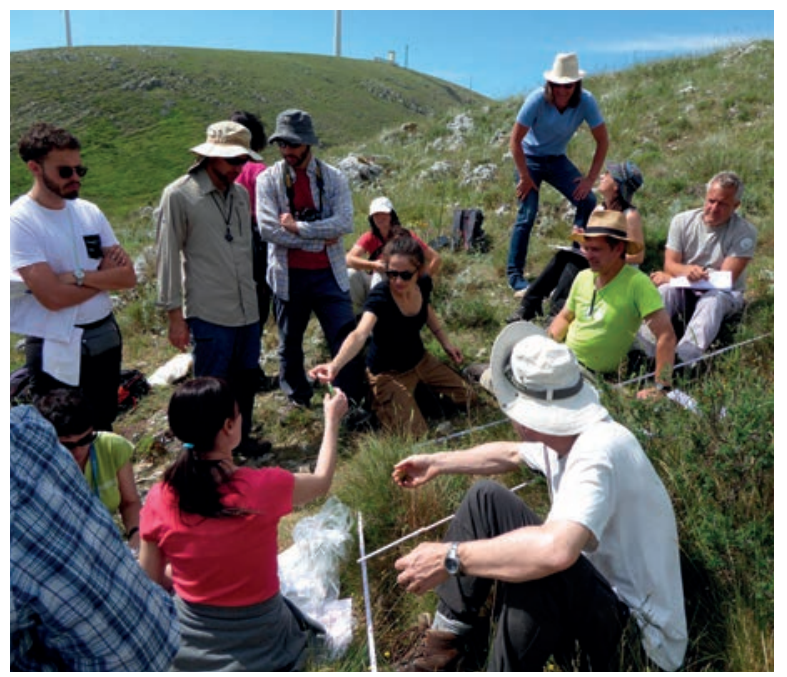


During the last two years, several publications based on data from previous expeditions have been published: Kuzemko et al. (2016) and Polyakova et al. (2016), on analyses of biodiversity patterns in grasslands from Central Podolia, Ukraine, and Khakassia, Russia, respectively. Dengler et al. (2016a) compiled all data from previous expeditions plus some additional data and provided the first overview on mean, maximum and minimum species richness in Palaearctic grasslands across seven spatial grain sizes, thus expanding on the scope of the highly cited "world-record paper" by Wilson et al. (2012). Kastrygina et al. (2016) described the new spider species Pulchellodromus navarrus on the basis of samples collected by Nina Polchaninova during the $7^{\text {th }}$ EDGG Field Workshop in Navarre, in 2014 (Biurrun et al. 2014). Many more studies based on EDGG Field Workshop data are currently in preparation.

\section{Publication activities associated with EDGG in 2016-2017}

The EDGG has published four issues of its own periodical, the Bulletin of the Eurasian Dry Grassland Group during the reported period (Issues 32-35), which are all openly available from http://www.edgg.org/publications. $\mathrm{htm}$. The Bulletin publishes contributions of EDGG members in full colour and free of charge, including free linguistic editing if necessary. Under the direction of Editor-in-Chief Anna Kuzemko, Deputy Editor-in-Chief Idoia Biurrun and the Editorial Board, the Bulletin now goes beyond announcements and reports of EDGG activities and short communications by our members and also regularly publishes full articles in the categories "Research paper", "Forum paper", "Review" and "Report", all of which receive a digital object identifier (DOI) to make them easily retrievable from literature databases, such as ResearchGate. Notable articles of the reporting period include the methodological paper on the EDGG multiscale sampling (Dengler et al. 2016b), an overview of mean and maximum richness values found in dry grasslands of different regions at different grain sizes (Dengler et al. 2016a) and a forum paper reflecting on the impact of armed conflicts on protected steppe areas in Ukraine (Vasyliuk et al. 2016).

The Hacquetia Special Issue (SI) on Fauna, flora, vegetation and conservation of Palaearctic natural and seminatural grasslands (Valkó et al. 2018), of which this report is part, contains contributions from the two previous EGCs, i.e. those in Sighişoara, Romania (2016) and Riga,
Latvia (2017). This is now the fourth SI published by the EDGG in Hacquetia, and plans are already in place for a fifth SI in 2019.

The EDGG has also continued its long-standing tradition of Special Issues/Features (SIs/SFs) in various international journals. Three more have been published over the past 1.5 years:

- In November 2016, Jürgen Dengler, Didem Ambarl1, Johannes Kamp, Péter Török and Karsten Wesche, completed a 400-page SI on Palaearctic Steppes: ecology, biodiversity and conservation in the journal Biodiversity and Conservation (see Török et al. 2016). This was the first among the many EDGG SFs/SIs that is completely devoted to the natural steppes of the Palaearctic. Among the 19 contributions, there was a synthesis paper by Wesche et al. (2016) aimed at summarizing the current status of knowledge of this biome.

- Also in November 2016, Monika Janišová, Jürgen Dengler and Wolfgang Willner completed an SI in Phytocoenologia on Classification of Palaearctic grasslands (see Janišová et al. 2016). Among the five papers included, there are broad-scale classifications of the SE European saline grasslands (Dajić Stevanović et al. 2016), the Ukrainian Molinio-Arrhenatheretea alliances (Kuzemko 2016) and the Tajik feather grass steppes (Nowak et al. 2016).

- The Virtual Special Feature (VSF) Towards a consistent classification of European grasslands in Applied Vegetation Science (Editors: Jürgen Dengler, Erwin Bergmeier, Milan Chytrý \& Wolfgang Willner) was completed in spring 2017. This VSF was a joint initiative of the two IAVS Working Groups, EDGG and EVS (European Vegetation Survey). It comprises a total of eight contributions from 2013-2017, beginning with an editorial laying out the scope, necessity and complexity of the enterprise (Dengler et al. 2013). This VSF assembled various broad-scale classification studies based on the analysis of thousands of vegetation plots that have become available from the European Vegetation Archive (EVA; Chytrý et al. 2016). Among the more recent contributions, García-Madrid et al. (2016) analysed the alliance Molinio-Holoschoenion in the Western Mediterranean region, Gavilán et al. (2017) provided a revision of the high-rank syntaxa of the acidophilous alpine grasslands of Iberia and Willner et al. (2017) a revision of the Festuco-Brometea communities of the Pannonian and Pontic regions of Europe.

- The $12^{\text {th }}$ EDGG SF in Tuexenia 37, published in June 2017, continues the series of such special features dealing with vegetation and conservation of grasslands in Central Europe s.l. It focuses on the conservation, management and biodiversity of semi- 
natural and natural grasslands in Central Europe. This special feature was edited by Thomas Becker, Balázs Deák, Anikó Csecserits and Viktoria Wagner (Deák et al. 2017). Altogether 41 authors from six countries (Denmark, Germany, Hungary, Italy, Serbia and Switzerland) contributed to the published papers. The $13^{\text {th }}$ EDGG SF in Tuexenia is already in preparation for publication in summer 2018 .

In 2017, EDGG authors were also heavily involved in the production of a book about global grasslands entitled Grasslands of the world: diversity, management and conservation (Squires et al. 2018). On behalf of the EDGG, Jürgen Dengler coordinated the eight chapters on $\mathrm{Pa}$ laearctic grasslands, which constitute approximately half of the book. These chapters cover the complete Palaearctic biogeographic realm, with very few exceptions, including Europe where the EDGG has always been strong (Ambarli et al. 2018, Dengler \& Tischew 2018, Reinecke et al. 2018, Török et al. 2018), and also North Africa and the Middle East (Ambarlı et al. 2018), the Asian part of Russia (Reinecke et al. 2018), Kazakhstan and Middle Asia (Bragina et al. 2018), China and Mongolia (Pfeiffer et al. 2018) and Japan (Ushimaru et al. 2018). Török \& Dengler (2018) synthesized the information from the constituent chapters in the first ever quantitative overview of the areas covered by different grassland types in all regions of the Palaearctic, as well as the relative importance of threat factors per region.

\section{EDGG activities in the field of vegetation-plot databases and resulting analyses}

Since its inception, the EDGG has been active in mobilising vegetation-plot data of grasslands for national and international analyses (see Janišová et al. 2017a). As a matter of fact, the Nordic-Baltic Grassland Vegetation Database (NBGVD; Dengler et al. 2006, Dengler \& Rūsina 2012; see http://bit.ly/2vzz3YT) was one of the main roots of the EDGG, as well as a founding member database of the European Vegetation Archive (EVA; Chytrý et al. 2016; see http://euroveg.org/eva-database). Another early member of EVA that is associated with the EDGG is the Ukrainian Grassland Database (Kuzemko 2012; see http://bit.ly/2s5Ch8U), while the Romanian Grassland Database (RGD; Vassilev et al. 2018; see https://www.bayceer.uni-bayreuth.de/ecoinformatics/en/ forschung/gru/html.php?id_obj=140287), the Balkan Dry Grassland Database (BDGD; Vassilev et al. 2012; see
http://bit.ly/2upRrDz) and the German Grassland Database (GrassVeg.DE; Dengler et al. 2017; see http://bit. ly/2qgX208), are among the fastest growing member databases of EVA, as well as the global plot database "sPlot" (Dengler \& sPlot Team 2014; see https://www.idiv.de/ splot). The EDGG-affiliated large grassland databases are run by self-governed consortia, each regulated by agreed bylaws and with elected custodians and deputy custodians. The good spatial coverage of data from otherwise not, or only poorly, represented regions, makes the EDGGaffiliated vegetation-plot databases critical also for some of the past (sub-) continental plot-based studies, such as the consistent classification of the Pannonian-Pontic Festuco-Brometea (Willner et al. 2017) or the data-driven definition of refined EUNIS grassland habitats (Schaminée et al. 2016). Furthermore, they also play a major role in on-going or forthcoming broad-scale studies on such topics as grassland classification, biodiversity patterns and drivers of biotic invasions in grasslands.

Last but not least, the EDGG Field Workshops are not only events of intensive fieldwork with an international group of enthusiastic grassland researchers, but their main purpose is the analysis of grassland diversity patterns across the Palaearctic realm via the collection of highly standardised datasets. In autumn 2016, we accordingly re-activated the former Database Species-Area Relationships in Palaearctic Grasslands (Dengler et al. 2012) to compile not only all the data from EDGG Field Workshops, but also comparable datasets from other researchers. During an international workshop in Bayreuth, Germany, in March 2017 (Figure 3), the database was then renamed "GrassPlot" as the large own data source of the EDGG, complementing EVA and managed by EVS

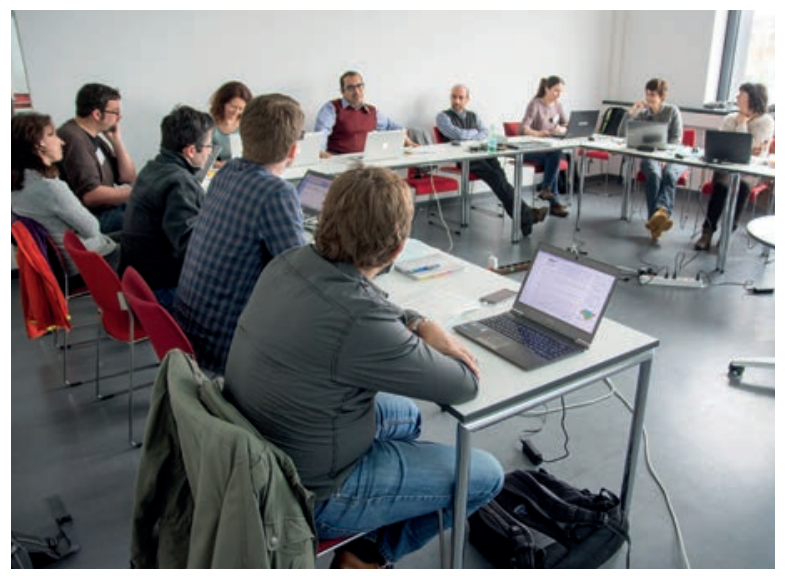

Figure 3: Impressions from the founding workshop of the GrassPlot consortium and database in Bayreuth, Germany, March 2017 (Photo: J. Dengler).

Slika 3: Vtisi z ustanovne delavnice konzorcija in podatkovne zbirke GrassPlot v mestu Bayreuth v Nemčiji marca 2017 (Foto: J. Dengler). 
through the provision of multi-scale richness and composition data from precisely delimited plots of grasslands and other open habitats to address specific research questions (Janišová et al. 2017b; see http://bit.ly/2qKTQt2). GrassPlot is growing very fast and has reached about 170,000 plots by January 2018. A first series of publications is planned for this year.

\section{References}

Ambarl, D., Vrahnakis, M., Burrascano, S., Naqinezhad, A. \& Pulido Fernández, M. 2018: Grasslands of the Mediterranean Basin and the Middle East and their management. In: Squires, V.R., Dengler, J., Feng, H. \& Hua, L. (eds.): Grasslands of the world: diversity, management and conservation. CRC Press, Boca Raton, US (in press).

Biurrun, I., García-Mijangos, I., Berastegi, A., Ambarlı, D., Dembicz, I., Filibeck, G., Jandt, U., Janišová, M., Jaunatre, R., (...) \& Dengler, J. 2014: Diversity of dry grasslands in Navarre (Spain): Experiences from the $7^{\text {th }}$ EDGG Field Workshop, 15-24 June 2014. Bulletin of the European Dry Grassland Group 24/25: 4-21.

Bragina, T.M., Nowak, A., Vanselow, K.A. \& Wagner, V. 2018: Grasslands of Kazakhstan and Middle Asia: the ecology, conservation and use of a vast and globally important area. In: Squires, V.R., Dengler, J., Feng, H. \& Hua, L. (eds.): Grasslands of the world: diversity, management and conservation. CRC Press, Boca Raton, US (in press).

Braun-Blanquet, J. 1961: Die inneralpine Trockenvegetation. Fischer, Stuttgart, $273 \mathrm{pp}$.

Chytrý, M., Hennekens, S.M., Jiménez-Alfaro, B., Knollová, I., Dengler, J., Jansen, F., Landucci, F., Schaminée, J.H.G, Aćić, S., (...) \& Yamalov, S. 2016: European Vegetation Archive (EVA): an integrated database of European vegetation plots. Applied Vegetation Science 19: 173-180.

Dajić Stevanović, Z., Aćić, S., Luković, M., Zlatković, I., Vasin, J., Topisirović, G. \& Šilc, U. 2016: Classification of continental halophytic grassland vegetation of Southeastern Europe. Phytocoenologia 46: 317-331.

Deák, B., Wagner, V., Csecserits, A. \& Becker, T. 2017: Vegetation and conservation of Central-European grasslands. Editorial to the $12^{\text {th }}$ EDGG Special Feature. Tuexenia 37: 375-378.

Dengler, J. \& Rūsina, S. 2012: Database Dry Grasslands in the Nordic and Baltic Region. Biodiversity \& Ecology 4: 319-320.

Dengler, J. \& sPlot Core Team. 2014: sPlot: the first global vegetationplot database and opportunities to contribute. IAVS Bulletin 2014(2): 34-37.

Dengler, J. \& Tischew, S. 2018: Grasslands of Western and Northern Europe - between intensification and abandonment. In: Squires,

V.R., Dengler, J., Feng, H. \& Hua, L. (eds.): Grasslands of the world: diversity, management and conservation. CRC Press, Boca Raton, US (in press).

Dengler, J., Rūsina, S., Boch, S., Bruun, H.H., Diekmann, M., Dierßen, K., Dolnik, C., Dupré, C., Golub, V.B., (...) \& Zobel, M. 2006: Working group on dry grasslands in the Nordic and Baltic region - Outline of the project and first results for the class FestucoBrometea. Annali di Botanica, Nuova Serie, 6: 1-28.
Dengler, J., Ruprecht, E., Szabó, A., Turtureanu, D., Beldean, M., Uğurlu, E., Pedashenko, H., Dolnik, C. \& Jones, A. 2009: EDGG cooperation on syntaxonomy and biodiversity of Festuco-Brometea communities in Transylvania (Romania): report and preliminary results. Bulletin of the European Dry Grassland Group 4: 13-19.

Dengler, J., Todorova, S., Becker, T., Boch, S., Chytrý, M., Diekmann, M., Dolnik, C., Dupré, C., Giusso del Galdo, G.P., (...) \& Vassilev, K. 2012: Database Species-Area Relationships in Palaearctic Grasslands. Biodiversity \& Ecology 4: 321-322.

Dengler, J., Bergmeier, E., Willner, W. \& Chytrý, M. 2013: Towards a consistent classification of European grasslands. Applied Vegetation Science 16: 518-520.

Dengler, J., Biurrun, I., Apostolova, I., Baumann, E., Becker, T., Berastegi, A., Boch, S., Dembicz, I., Dolnik, C., (...) \& Weiser, F. 2016a: Scale-dependent plant diversity in Palaearctic grasslands: a comparative overview. Bulletin of the Eurasian Dry Grassland Group 31: $12-26$

Dengler, J., Boch, S., Filibeck, G., Chiarucci, A., Dembicz, I., Guarino, R., Henneberg, B., Janišová, M., Marcenò, C., (...) \& Biurrun, I. 2016b: Assessing plant diversity and composition in grasslands across spatial scales: the standardised EDGG sampling methodology. Bulletin of the Eurasian Dry Grassland Group 32: 13-30.

Dengler, J., Becker, T., Conradi, T., Dolnik, C., Heindl-Tenhunen, B., Jensen, K., Kaufmann, J., Klotz, M., Kurzböck, C., (...) \& Went, J. 2017: GrassVeg.DE - die neue kollaborative Vegetationsdatenbank für alle Offenlandhabitate Deutschlands. Tuexenia 37: 447-455.

Filibeck, G., Cancellieri, L., Sperandii, M.G., Belonovskaya, E., Sobolev, N., Tsarevskaya, N., Becker, T., Berastegi, A., (...), Dengler, J. \& Biurrun, I. 2018: Biodiversity patterns of dry grasslands in the Central Apennines (Italy) along a precipitation gradient: experiences and first results from the 10th EDGG Field Workshop. Bulletin of the Eurasian Dry Grassland Group 36 (in press).

García-Madrid, A.S., Rodríguez-Rojo, M.P., Cantó, P. \& Molina, J.A. 2016: Diversity and classification of tall humid herb grasslands (Molinio-Holoschoenion) in Western Mediterranean Europe. Applied Vegetation Science 19: 736-749.

Gavilán, R.G., Vilches, B., Font, X. \& Jiménez-Alfaro, B. 2017: A review of high-mountain acidophilous vegetation in the Iberian Peninsula. Applied Vegetation Science 20: 513-526.

Janišová, M., Dengler, J. \& Willner, W. 2016: Classification of Palaearctic grasslands. Phytocoenologia 46: 233-239.

Janišová, M., Biurrun, I., Dengler, J., Vassilev, K. \& Kuzemko, A. 2017a: Invitation to contribute to the vegetation-plot databases of EDGG. Bulletin of the Eurasian Dry Grassland Group 34: 14-18.

Janišová, M., Dengler, J. \& Biurrun, I. 2017b: GrassPlot - The new database of multi-scale plant diversity of Palaearctic grasslands. IAVS Bulletin 2017(2): 18-22.

Kastrygina, Z.A., Kovblyuk, M.M. \& Polchaninova, N.Y. 2016: A new species of the genus Pulchellodromus Wunderlich, 2012 (Aranei: Philodromidae) from Spain. Arthropoda Selecta 25: 293-296.

Kuzemko, A. 2012: Ukrainian Grasslands Database. Biodiversity \& Ecology 4: 430-430.

Kuzemko, A. 2016: Classification of the class Molinio-Arrhenatheretea in the forest and forest-steppe zones of Ukraine. Phytocoenologia 46: 241-256. 
Kuzemko, A., Steinbauer, M.J., Becker, T., Didukh, Y.P., Dolnik, C., Jeschke, M., Naqinezhad, A., Ugurlu, E., Vassilev, K. \& Dengler, J. 2016: Patterns and drivers of phytodiversity in steppe grasslands of Central Podolia (Ukraine). Biodiversity and Conservation 25: 2233-2250.

Nowak, A., Nowak, S., Nobis, A. \& Nobis, M. 2016: Vegetation of feather grass steppes in the western Pamir Alai Mountains (Tajikistan, Middle Asia). Phytocoenologia 46: 295-315.

Pfeiffer, M., Dulamsuren, C., Jäschke, Y. \& Wesche, K. 2018: Grasslands of China and Mongolia: spatial extent, land use and conservation. In: Squires, V.R., Dengler, J., Feng, H. \& Hua, L. (eds.): Grasslands of the world: diversity, management and conservation. CRC Press, Boca Raton, US (in press).

Polyakova, M.A., Dembicz, I., Becker, T., Becker, U., Demina, O.N., Ermakov, N., Filibeck, G., Guarino, R., Janišová, M., (...) \& Dengler, J. 2016: Scale- and taxon-dependent patterns of plant diversity in steppes of Khakassia, South Siberia (Russia). Biodiversity and Conservation 25: 2251-2273.

Reinecke, J.S.F., Smelansky, I.E., Troeva, E.I., Trofimov, I.A. \& Trofimova, L.S. 2018: Land use of natural and secondary grasslands in Russia. In: Squires, V.R., Dengler, J., Feng, H. \& Hua, L. (eds.): Grasslands of the world: diversity, management and conservation. CRC Press, Boca Raton, US (in press).

Rūsiṇa, S., Gustina, L., Sniedze-Kretalova, R., Rašomavičius, V., Uogintas, D., Silamiķele, I., Vrahnakis, M. \& Ambarlı, D. 2017: Report from the $14^{\text {th }}$ Eurasian Grassland Conference. 4-11 July 2017 in Riga, Latvia and western Lithuania. Bulletin of the Eurasian Dry Grassland Group 35: 11-19.

Schaminée, J.H.J., Chytrý, M., Dengler, J., Hennekens, S.M., Janssen, J.A.M., Jiménez-Alfaro, B., Knollová, I., Landucci, F., Marcenò, C., (...) \& Tichý, L. 2016: Development of distribution maps of grasslands habitats of EUNIS habitat classification. Report EEA/NSS/16/005. Alterrra, NL

Squires, V.R., Dengler, J., Feng, H. \& Hua, L. (eds.) 2018: Grasslands of the world: diversity, management and conservation. CRC Press, Boca Raton, US (in press).

Sutcliffe, L., Akeroyd, J., Gherghiceanu, L., Mountford, O., Page, N., Ruprecht, E., Ambarlı, D. \& Vrahnakis, M. 2016: Post-conference report for the $13^{\text {th }}$ Eurasian Grassland Conference 2016 in Sighişoara, Romania. Bulletin of the Eurasian Dry Grassland Group 32: 3-9.

Török, P. \& Dengler, J. 2018: Palaearctic grasslands in transition: overarching patterns and future prospects. In: Squires, V.R., Dengler, J., Feng, H. \& Hua, L. (eds.): Grasslands of the world: diversity, management and conservation. CRC Press, Boca Raton, US (in press).

Török, P., Wesche, K., Ambarlı, D., Kamp, J. \& Dengler, J. 2016: Step(pe) up! Raising the profile of the Palaearctic natural grasslands. Biodiversity and Conservation 25: 2187-2196.

Török, P., Janišová, M., Kuzemko, A., Rūsiṇa, S. \& Dajić Stevanović, Z. 2018: Grasslands, their threats and management in Eastern Europe. In: Squires, V.R., Dengler, J., Feng, H. \& Hua, L. (eds.): Grasslands of the world: diversity, management and conservation. CRC Press, Boca Raton, US (in press).

Ushimaru, A., Uchida, K. \& Suka, T. 2018: Grassland biodiversity in Japan: threats, management and conservation. In: Squires, V.R., Dengler, J., Feng, H. \& Hua, L. (eds.): Grasslands of the world: diversity, management and conservation. CRC Press, Boca Raton, US (in press).
Valkó, O., Venn, S., Loos, J., Biurrun, I., Labadessa, R. \& Zmihorski, M. 2018: The challenge of abandonment for the sustainable management of Palaearctic natural and semi-natural grasslands. Hacquetia 17(1): 5-16.

Vassilev, K., Dajić, Z., Cušterevska, R., Bergmeier, E. \& Apostolova, I. 2012: Balkan Dry Grasslands Database. Biodiversity \& Ecology 4: 330-330.

Vassilev, K., Ruprecht, E., Alexiu, V., Becker, T., Beldean, M., BițăNicolae, C., Csergő, A.M., Dzhovanova, I., Filipova, E., (...) \& Dengler, J. 2018: The Romanian Grassland Database (RGD): historical background, current status and future perspectives. Phytocoenologia 48. DOI: $10.1127 /$ phyto/2017/0229 (in press).

Vasyliuk, O., Shyriaieva, D., Kolmytsev, G. \& Spinova, J. 2016: Steppe protected areas on the territory of Ukraine in the context of the armed conflict in the Donbas region and Russian annexation of the Crimean Peninsula. Bulletin of the Eurasian Dry Grassland Group 33: $15-23$.

Venn, S., Ambarlı, D., Biurrun, I., Dengler, J., Janišová, M., Kuzemko, A., Török, P. \& Vrahnakis, M. 2016: The Eurasian Dry Grassland Group (EDGG) 2015-2016. Hacquetia 15(2): 15-19.

Vrahnakis, M.S., Janišová, M., Rūsin̨a, S., Török, P., Venn, S. \& Dengler, J. 2013: The European Dry Grassland Group (EDGG): stewarding Europe's most diverse habitat type. In: Baumbach, H. \& Pfützenreuter, S. (eds.): Steppenlebensräume Europas - Gefährdung, Erhaltungsmaßnahmen und Schutz. Thüringer Ministerium für Landwirtschaft, Forsten, Umwelt und Naturschutz, Erfurt, pp. 417-434.

Wesche, K., Ambarlı, D., Kamp, J., Török, P., Treiber, J. \& Dengler, J. 2016: The Palaearctic steppe biome: a new synthesis. Biodiversity and Conservation 25: 2197-2231.

Willner, W., Kuzemko, A., Dengler, J., Chytrý, M., Bauer, N., Becker, T., Biță-Nicolae, C., Botta-Dukát, Z., Čarni, A., (...) \& Janišová, M. 2017: A higher-level classification of the Pannonian and western Pontic steppe grasslands (Central and Eastern Europe). Applied Vegetation Science 20: 143-158.

Wilson, J.B., Peet, R.K., Dengler, J. \& Pärtel, M. 2012: Plant species richness: the world records. Journal of Vegetation Science 23: 796-802. 